\title{
Design, Simulation and Experimental Analysis on Rectangular Microstrip Patch Antenna with Superstrates
}

\author{
V. Saidulu
}

\begin{abstract}
This paper focuses on design, simulation and experimental analysis of rectangular MSA with and without superstrates. The rectangular MPA is designed at frequency range of $2.40 \mathrm{GHz}$, which is lying in the $S$ band region. The transmission line model analysis and High Frequency Simulation Software (HFSS) is used for designing of proposed rectangular MPA. The proposed antenna is fabricated on Arlon diclad 880 substrate, whose dielectric constant is 2.2, thickness of the substrate is $1.6 \mathrm{~mm}$ and loss tangent is 0.0009 . In this paper the effect of dielectric superstrates on rectangular MPA and the height of superstrate are varying above the rectangular MPA is investigated experimentally and compared with simulated and measured results. The proposed antenna has been analyzed using different dielectric superstrates. From the study it was observed that in antenna without superstrate the VSWR is 1.21, return loss is $-18.51 \mathrm{~dB}$, bandwidth is $0.038 \mathrm{GHz}$. However, gain is $8.77 \mathrm{~dB}$. In the antennas with superstrates, center frequency is shifted from $2.40 \mathrm{GHz}$ to $2.33 \mathrm{GHz}$ as well as other parameters are slightly degraded. As superstrate height increases, the performance antenna is degraded and at particular optimum height the performance characteristics of antenna with and without superstrate will be same. The frequency range $2.40 \mathrm{GHz}$ is used in wireless applications.
\end{abstract}

Keywords: Bandwidth, Gain, Superstrate, Voltage Standing Ratio.

\section{INTRODUCTION} applications such as wireless and mobile communications [1]. The rectangular microstrip antenna as compared with the conventional microwave antenna is simple and easy to design and also fabricated on printed circuit board. The antenna has several limitations such as low bandwidth and low gain when compared to the conventional microwave antenna. The gain and bandwidth of microstrip antenna can be increased by placing superstrate above the patch. The rectangular microstrip patch antenna are widely used in aerospace, military and satellite communication applications [2-5]. In these applications microstrip antenna are often covered with radom (cover) or dielectric superstrates to provide the protection from environmental effects[1], [5-11]. This paper mainly focused on the study of the effect of superstrates on antenna characteristics for the following three cases:

Revised Manuscript Received on February 15, 2020.

* Correspondence Author

V. Saidulu, Associate Professor, Department of ECE, Mahatma Gandhi Institute of Technology, Gandipet, Hyderabad. E-mail: saiduluvadtya@gmail.com.

(c) The Authors. Published by Blue Eyes Intelligence Engineering and Sciences Publication (BEIESP). This is an open access article under the CC BY-NC-ND license (http://creativecommons.org/licenses/by-nc-nd/4.0/)
The rectangular MPA's are most widely used in many

i. Analysis of single patch antenna without superstrate.

ii. Analysis of superstrate effect touching the patch antenna at height $(\mathrm{H})=0(\mathrm{~mm})$

iii. Superstrate effect above the patch antenna at optimum height $\left(H_{\text {opt }}\right)=\mathrm{H}(\mathrm{mm})$

At an optimum height the performance characteristics of antenna with and without superstrate will be same. The top and side view of rectangular MPA with superstrate are shown in Fig. 1 \& 2.

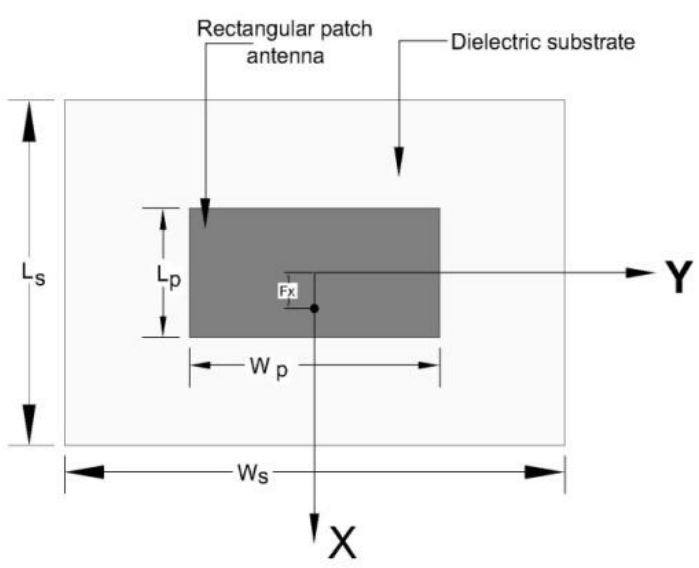

Fig 1. The top view of rectangular MPA, $W=49.5 \mathrm{~mm}, \mathrm{~L}$ $=40.3 \mathrm{~mm}, \mathrm{~h}=1.6 \mathrm{~mm}, \epsilon_{r}=2.2$

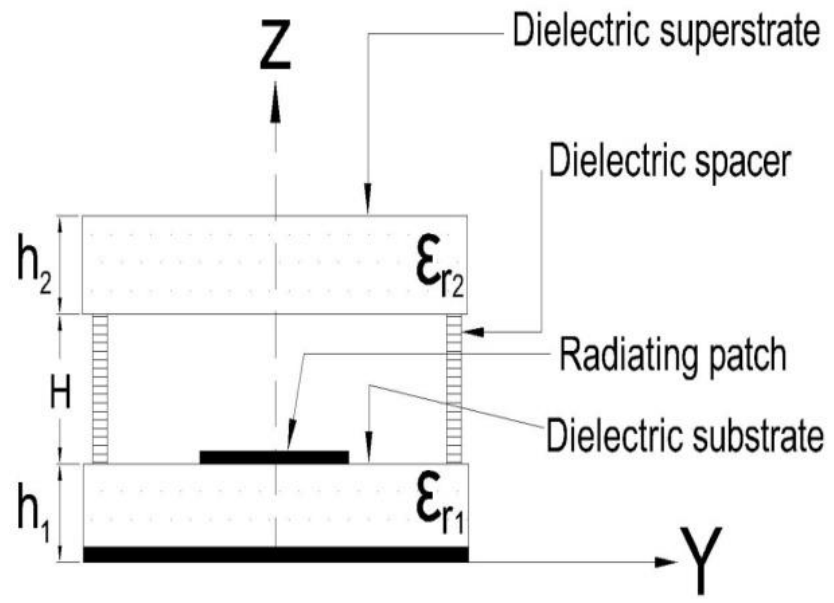

Fig 2. The side view of rectangular MPA with superstrates at height $\mathrm{H} \mathrm{mm}$ 


\section{ANTENNA SPECIFICATIONS}

The rectangular MPA is designed and fabricated on Arlon diclad 880 substrate which is having dielectric constant $\left(\epsilon_{r 1}\right)$ 2.2 and thickness $\left(h_{1}\right)$ is $1.6 \mathrm{~mm}$. However, superstrates materials used such as Air, Arlon diclad 880, Arlon AD 320, FR4, and Arlon AD 1000 have dielectric constants $\left(\epsilon_{r 2}\right)$ $1.0,2.2,3.2,4.8,10.2$ and thickness $\left(h_{2}\right) 0.0,1.6 \mathrm{~mm}$, $3.2 \mathrm{~mm}, 1.6 \mathrm{~mm}, 0.8 \mathrm{~mm}$. The higher dielectric constant material gives more loss as compared to low dielectric constant of the substrates materials [1-11].

\section{ANTENNA DESIGN GEOMETRY}

The transmission line model and coaxial probe feed techniques are used for designing rectangular MPA. The designed dimensions of rectangular MPA are shown in Table I.

Table I: Design of antenna dimensions

\begin{tabular}{|l|l|l|l|l|}
\hline $\begin{array}{l}W_{S} \\
(\mathbf{m m})\end{array}$ & $\boldsymbol{L}_{\boldsymbol{S}} \mathbf{( \mathbf { m m } )}$ & $\boldsymbol{W}_{\boldsymbol{P}}(\mathbf{m m})$ & $\boldsymbol{L}_{\boldsymbol{P}}(\mathbf{m m})$ & $\begin{array}{l}\text { Feed } \\
\text { point } \\
\left(\boldsymbol{F}_{\boldsymbol{X}} \boldsymbol{F}_{\boldsymbol{Y}}\right)\end{array}$ \\
\hline 81.3 & 72.3 & 49.5 & 40.3 & $10.3,0$ \\
\hline
\end{tabular}

\section{DIELECTRIC SUPERSTRATE EFFECT}

The formula used for fractional change in resonant frequency is given

$$
\begin{aligned}
\frac{\nabla f_{r}}{f_{r}} & =\frac{\sqrt{\epsilon_{e}}-\sqrt{\epsilon_{e o}}}{\sqrt{\epsilon_{e}}} \\
\text { If } \epsilon_{e} & =\epsilon_{e o}+\nabla \epsilon_{e} \text { and } \nabla \epsilon_{e} \leq 0.1 \epsilon_{e o}, \\
\frac{\Delta f_{r}}{f_{r}} & =1 / 2 \frac{\Delta \epsilon_{e} / \epsilon e_{o}}{1+1 / 2^{\Delta \epsilon_{e} / \epsilon e_{o}}}
\end{aligned}
$$

Where,

$\epsilon_{e}=$ Dielectric constant with dielectric superstrate $\in e_{o}=$ Dielectric constant without dielectric superstrate $\Delta \epsilon_{e}=$ Change in dielectric constant,

$\Delta f_{r}=$ Change in center frequency

$f_{r}=$ Center frequency

\section{SIMULATED AND MEASUREMENT RESULTS}

Dielectric constant $\left(\epsilon_{r 2}\right)=1$ is considered as antenna without dielectric superstrate and dielectric constant $\left(\epsilon_{r 2}\right)=2.2$, 3.2, 4.8 and 10.2 are considered as antenna with dielectric superstrates at $\mathrm{H}=0$ (mm) and optimum height with superstrate $\mathrm{H}$ mm. The simulation result have been carried out for superstrates of various dielectric constants of $\epsilon_{r 2}$ $=2.2,3.2,4.8$ and 10.2. For superstrates of different dielectric constants, it is observed that the center frequency is decreased to $2.08 \mathrm{GHz}$ from $2.4 \mathrm{GHz}$, bandwidth is decreased to $0.03 \mathrm{GHz}(\mathrm{SWR}<2)$ from $0.04 \mathrm{GHz}$ and gain is decreased to $6.0 \mathrm{~dB}$ from $8.75 \mathrm{~dB}$. Further in the study, it was also found that as the height of the superstrate increases the performance of the patch antenna increased and at a particular optimum height the performance characteristics of patch antenna with and without superstrate will be same. Further, it has also been observed that the HPBW decreases in azimuth plane where as it increases in the elevation plane. It is also observed that the gain of the MPA decreases with increasing dielectric constant of the superstrates. The return-loss and radiation patterns are shown in Fig. 4 and Fig. 5 for $\epsilon_{r 2}=2.2$. It is observed that the impedance bandwidth without superstrates is $0.04 \mathrm{GHz}$ and with superstrate $0.03 \mathrm{GHz}(\mathrm{SWR} \leq 2)$. The overall results are given in Table II to $\mathrm{V}$ for $\epsilon_{r 2}=2.2$, 3.2, 4.8 and 10.2 at height $(\mathrm{H})=0 \mathrm{~mm}$ and optimum heights. The result observed from the Table III and Table V are, the gain slightly decreases in azimuth plane and increases in elevation plane. The return-loss and VSWR increases as the superstrate dielectric constant increases. The typical plots such as return-loss and radiation patterns for dielectric constants $\epsilon_{r 2}=2.2$, are shown in Figs. 6 to 9.

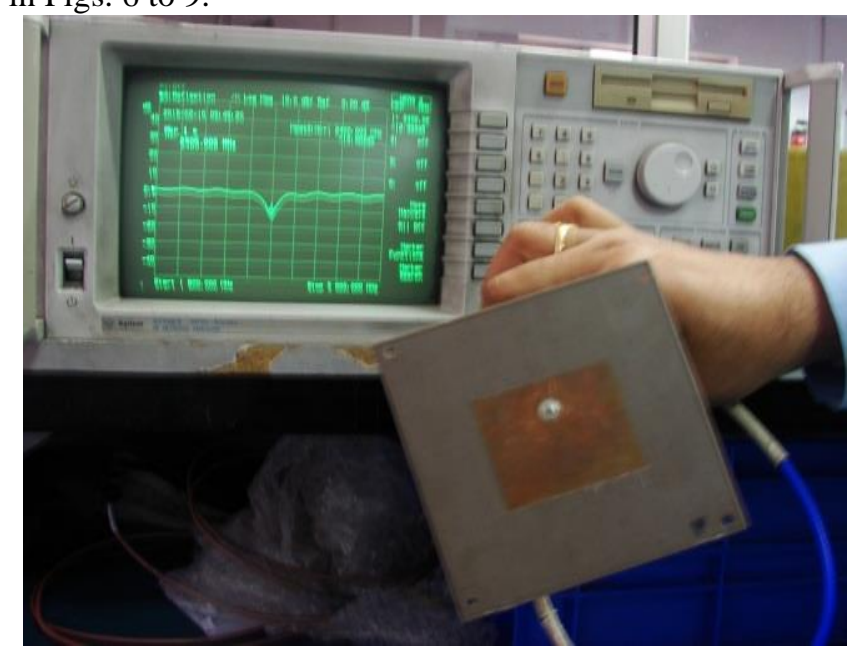

Fig. 3 Prototype of the fabricated rectangular patch antenna return- loss measurement.

\section{A. Result of patch antenna without superstrate}

From Figs. 4 and 5, it is observed that the return loss is $-18.51 \mathrm{~dB}$, VSWR is 1.27 and bandwidth is $0.038 \mathrm{GHz}$. However, the gain is $8.77 \mathrm{~dB}$.

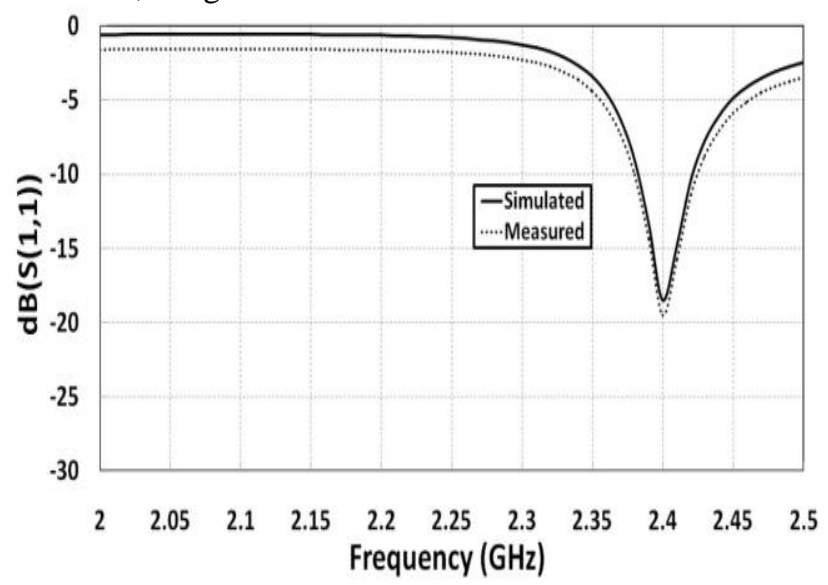

Fig. 4 Return-loss for RMA without dielectric superstrate $\left(\epsilon_{\mathbf{r} 1}\right)=2.2$

Fig. 5 also illustrates that the center frequency is $2.40 \mathrm{GHz}$, $\mathrm{BW}$ is $0.041 \mathrm{GHz}$ and the simulated gain is $8.77 \mathrm{~dB}$, where as measured result is $8.75 \mathrm{~dB}$. 


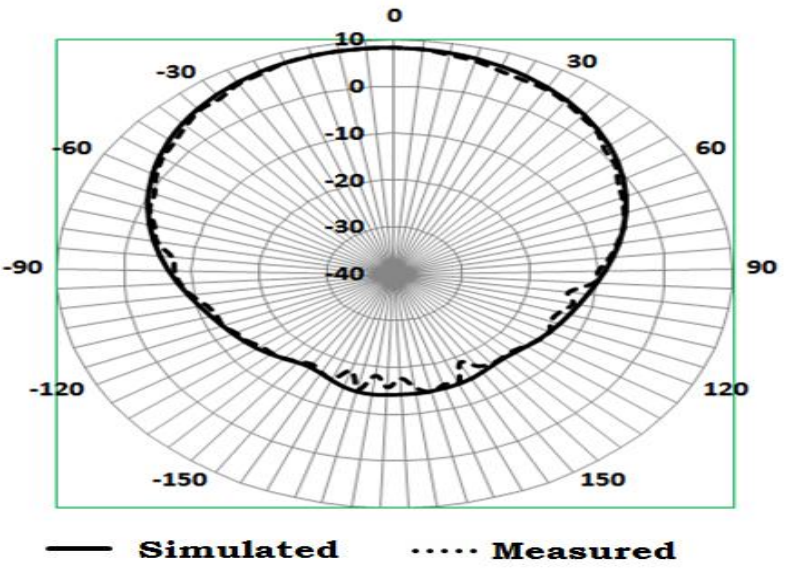

Fig. 5 Radiation patterns for RMPA in E-plane $\epsilon_{\mathrm{r} 1}=2.2$ without dielectric superstrate at $2.40 \mathrm{GHz}$.

\section{B. Results of patch antenna with superstrates}

The rectangular MPA has been analyzed using dielectric superstrates of dielectric constant 2.2, 3.2, 4.8 and 10.2. The obtained characteristics are shown in Figs 6 to 9. The simulated and measured results are shown in Tables IV and V.

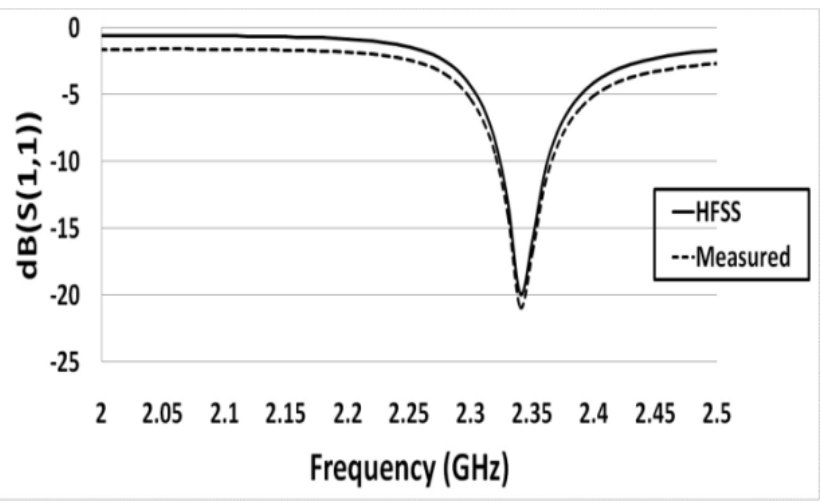

Fig. 6 Return-loss for RMPA with superstrate $\left(\epsilon_{\mathrm{r} 1}\right)=$ 2.2.

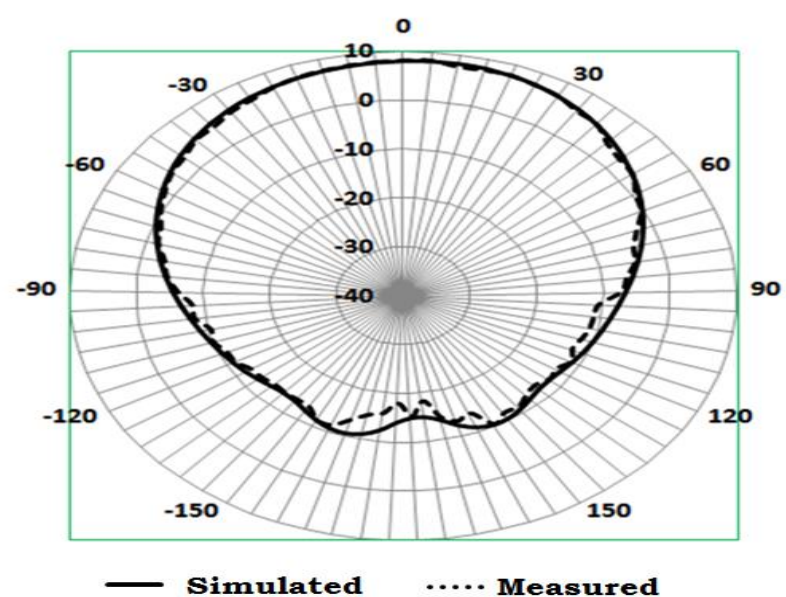

Fig. 7 Radiation patterns of RMPA in E-plane for $\epsilon_{\mathrm{r} 2}=$ 2.2, $\Phi=0, f_{r}=2.34 \mathrm{GHz}$

From the simulated and experimental results it is found that the gain of patch antenna is decreased as increasing dielectric constant of the superstrates. The simulated and measured results show that the resonant frequency has decreased to $2.34 \mathrm{GHz}$ from $2.40 \mathrm{GHz}$; BW has decreased to $0.032 \mathrm{GHz}$ from $0.038 \mathrm{GHz}$, gain has decreased to $8.67 \mathrm{~dB}$ from $8.77 \mathrm{~dB}$. The return-loss and VSWR increased as increasing dielectric constant of the superstrates. The return-loss increased from -18.51 to $-19.91 \mathrm{~dB}$ for various dielectric constants of superstrates. The same trend is observed in the measured results for other dielectric constants are shown in Table II to V.

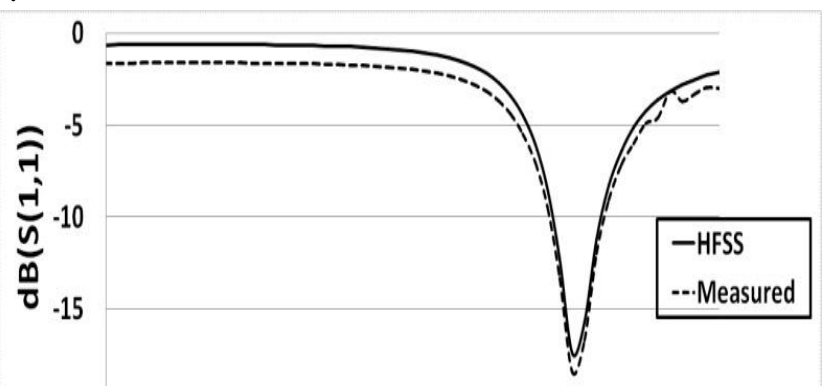

$-20$

$\begin{array}{lllllllllll}2 & 2.05 & 2.1 & 2.15 & 2.2 & 2.25 & 2.3 & 2.35 & 2.4 & 2.45 & 2.5\end{array}$

Frequency $(\mathrm{GHz})$

Fig 8: Return loss for RMPA with superstrate $\epsilon_{\mathrm{r} 2}=4.8$, $h_{2}=1.60 \mathrm{~mm}$

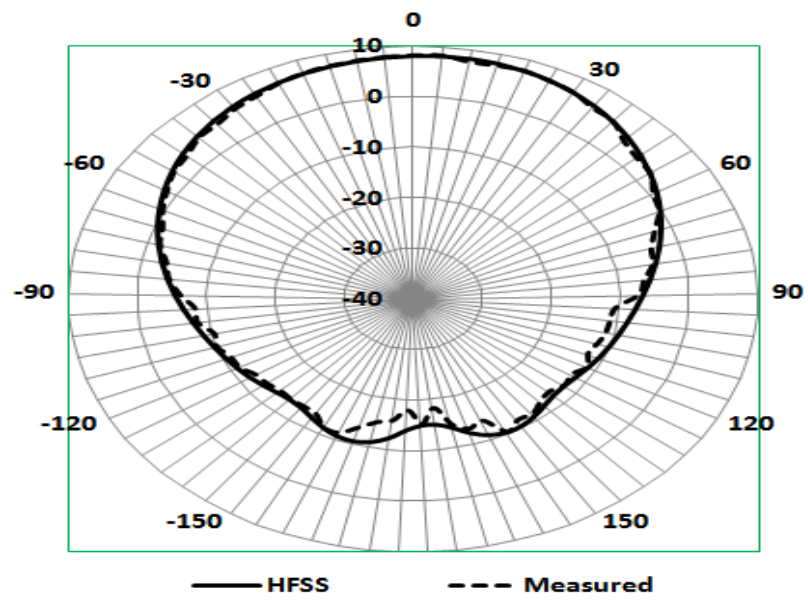

(a) $\Phi=0^{0}, \mathrm{H}=0$

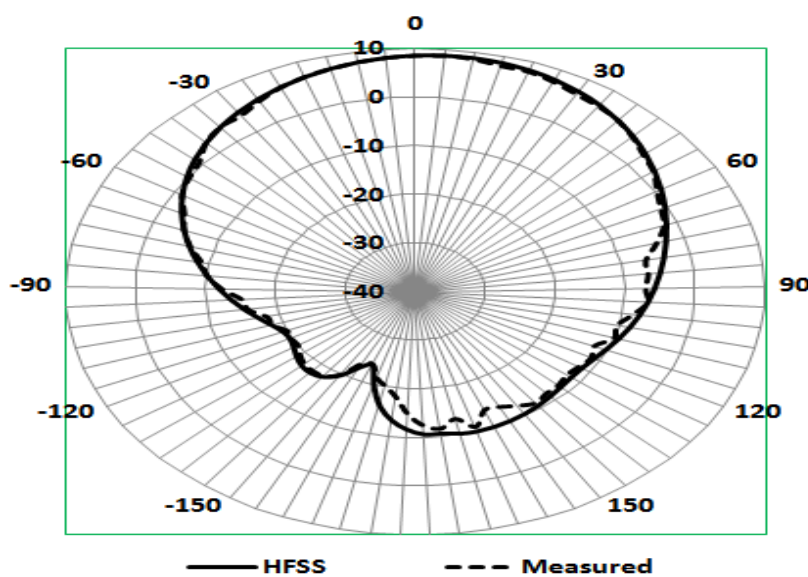

(b) $\Phi=90^{\circ}, \mathrm{H}=\mathrm{H}_{\mathrm{opt}}$

Fig 9: Measured and simulated radiation patterns (a) In E-plane for $\epsilon_{r 2}=2.2, h_{2}=1.6 \mathrm{~mm}$ at $\mathrm{H}=0 \mathrm{~mm}$ (b)

In H-Plane $\epsilon_{r 2}=4.8, h_{2}=1.6 \mathrm{~mm}$ at $\mathrm{H}=\mathrm{H}_{\text {opt }}$

Published By:

Blue Eyes Intelligence Engineering DOI: 10.35940/ijeat.B4671.029320 Journal Website: www.ijeat.org 
Table II: Measured and simulated results of RMPA with and without dielectric superstates at height $\mathrm{H}=0$

\begin{tabular}{|c|c|c|c|c|c|c|}
\hline \multicolumn{7}{|c|}{ (mm) } \\
\hline \multicolumn{2}{|c|}{$\begin{array}{c}\text { Superstrate } \\
\text { dielectric constants } \\
\left(\in_{r}\right)\end{array}$} & $1^{*}$ & 2.2 & 3.2 & 4.8 & 10.2 \\
\hline \multicolumn{2}{|c|}{$\begin{array}{l}\text { Optimum Height } \\
(\mathrm{H}), \mathrm{mm}\end{array}$} & $\begin{array}{c}31.2 \\
5\end{array}$ & $\begin{array}{c}21.0 \\
7\end{array}$ & 17.46 & $\begin{array}{c}14.2 \\
6\end{array}$ & 9.78 \\
\hline \multirow{2}{*}{$\begin{array}{c}\text { Center } \\
\text { frequenc } \\
\mathrm{y} \\
\left(f_{0}\right), \mathrm{GHz} \\
\end{array}$} & $\begin{array}{c}\text { Simulat } \\
\text { ed }\end{array}$ & 2.40 & 2.34 & 2.31 & 2.26 & 2.08 \\
\hline & $\begin{array}{l}\text { Measur } \\
\text { ed }\end{array}$ & 2.40 & 2.34 & 2.31 & 2.26 & 2.08 \\
\hline \multirow{2}{*}{$\begin{array}{c}\text { Band } \\
\text { width(G } \\
\text { Hz) }\end{array}$} & $\begin{array}{c}\text { Simulat } \\
\text { ed }\end{array}$ & 0.04 & 0.03 & 0.03 & 0.03 & 0.03 \\
\hline & $\begin{array}{c}\text { Measur } \\
\text { ed }\end{array}$ & 0.04 & 0.03 & 0.03 & 0.03 & 0.03 \\
\hline \multirow{2}{*}{$\begin{array}{l}\text { Return } \\
\text { loss(dB) }\end{array}$} & $\begin{array}{c}\text { Simulat } \\
\text { ed }\end{array}$ & $\begin{array}{c}-18.5 \\
1 \\
\end{array}$ & $\begin{array}{c}-19.9 \\
1 \\
\end{array}$ & -20.46 & $\begin{array}{c}-21.2 \\
9\end{array}$ & $\begin{array}{c}-25.6 \\
4\end{array}$ \\
\hline & $\begin{array}{l}\text { Measur } \\
\text { ed }\end{array}$ & -19.0 & -17.8 & -22.0 & -21.0 & $\begin{array}{c}-26.6 \\
4\end{array}$ \\
\hline
\end{tabular}

*without dielectric superstrate

Table III: Measured and simulated results of RMPA with and without dielectric superstates at optimum height $\mathbf{H}=\mathbf{0}(\mathrm{mm})$

\begin{tabular}{|c|c|c|c|c|c|c|c|c|}
\hline \multirow{2}{*}{$\begin{array}{c}\text { Diele } \\
\text { ctric } \\
\text { const } \\
\text { ant }\end{array}$} & \multicolumn{4}{|c|}{ HPBW(deg.) } & \multicolumn{4}{c|}{ Gain(dB) } \\
\cline { 2 - 9 } & $\begin{array}{c}\text { Simulated } \\
\text { mut } \\
\text { h }\end{array}$ & $\begin{array}{c}\text { Elev } \\
\text { ation }\end{array}$ & $\begin{array}{c}\text { Azi } \\
\text { mut } \\
\text { h }\end{array}$ & $\begin{array}{c}\text { Elev } \\
\text { ation }\end{array}$ & $\begin{array}{c}\text { Azi } \\
\text { mut } \\
\text { h }\end{array}$ & $\begin{array}{c}\text { Elev } \\
\text { ation }\end{array}$ & $\begin{array}{c}\text { Azi } \\
\text { mut } \\
\text { h }\end{array}$ & $\begin{array}{c}\text { Elev } \\
\text { ation }\end{array}$ \\
\hline $1^{*}$ & 70.8 & 71.1 & $\begin{array}{c}71.2 \\
7\end{array}$ & $\begin{array}{c}71.2 \\
3\end{array}$ & 8.77 & 8.16 & 8.75 & 8.10 \\
\hline 2.2 & 60.7 & 85.4 & $\begin{array}{c}61.5 \\
2\end{array}$ & 85.8 & 8.67 & 7.85 & 8.60 & 7.90 \\
\hline 3.2 & 57.4 & 95.8 & $\begin{array}{c}57.8 \\
9\end{array}$ & $\begin{array}{c}95.8 \\
1\end{array}$ & 8.26 & 7.34 & 8.30 & 7.30 \\
\hline 4.8 & 53.8 & 101. & 54.5 & $\begin{array}{c}101 . \\
7\end{array}$ & 7.76 & 7.06 & 7.77 & 7.00 \\
\hline 10.2 & 49.1 & $\begin{array}{c}112 . \\
0\end{array}$ & $\begin{array}{c}49.3 \\
5\end{array}$ & $\begin{array}{c}112 . \\
67\end{array}$ & 6.02 & 6.59 & 6.00 & 6.50 \\
\hline
\end{tabular}

${ }^{*}$ without dielectric superstrate

Table IV: Measured and simulated results of RMPA with and without dielectric superstates at optimum height $\mathbf{H}=$ Hopt (mm)

\begin{tabular}{|l|l|c|c|c|c|c|}
\hline \multicolumn{2}{|c|}{$\begin{array}{c}\text { Superstrate dielectric } \\
\text { constants }\left(\in_{r}\right)\end{array}$} & $1^{*}$ & 2.2 & 3.2 & 4.8 & 10.2 \\
\hline \multicolumn{2}{|c|}{ Optimum Height $(\mathrm{H}), \mathrm{mm}$} & 31.25 & 21.07 & 17.46 & $\begin{array}{c}14.2 \\
6\end{array}$ & 9.78 \\
\hline $\begin{array}{l}\text { Center } \\
\text { frequency(fo),G } \\
\text { Hz }\end{array}$ & $\begin{array}{l}\text { Simulate } \\
\mathrm{d}\end{array}$ & 2.40 & 2.38 & 2.39 & 2.40 & 2.40 \\
\cline { 2 - 7 } & $\begin{array}{l}\text { Measure } \\
\mathrm{d}\end{array}$ & 2.40 & 2.38 & 2.39 & 2.40 & 2.40 \\
\hline $\begin{array}{l}\text { Band } \\
\text { width(GHz) }\end{array}$ & $\begin{array}{l}\text { Simulate } \\
\mathrm{d}\end{array}$ & 0.04 & 0.04 & 0.04 & 0.04 & 0.04 \\
\cline { 2 - 7 } & $\begin{array}{l}\text { Measure } \\
\mathrm{d}\end{array}$ & 0.04 & 0.04 & 0.04 & 0.04 & 0.04 \\
\hline Return loss(dB) & $\begin{array}{l}\text { Simulate } \\
\mathrm{d}\end{array}$ & -17.5 & -17.4 & -16.4 & -14. & -11.1 \\
\cline { 2 - 7 } & $\begin{array}{l}\text { Measure } \\
\mathrm{d}\end{array}$ & -20.4 & -18.8 & -15.8 & $\begin{array}{c}-14 . \\
6\end{array}$ & $\begin{array}{c}-12.1 \\
5\end{array}$ \\
\hline
\end{tabular}

Table V: Measured and simulated results of RMPA with and without dielectric superstates at optimum height $H$ $=$ Hopt $(\mathbf{m m})$

\begin{tabular}{|c|c|c|c|c|c|c|c|c|}
\hline \multirow{2}{*}{$\begin{array}{c}\text { Diele } \\
\text { ctric } \\
\text { const } \\
\text { ant }\end{array}$} & \multicolumn{4}{|c|}{ HPBW(deg.) } & \multicolumn{4}{c|}{ Gain(dB) } \\
\cline { 2 - 9 } & $\begin{array}{c}\text { Simulated } \\
\text { mut } \\
\text { h }\end{array}$ & $\begin{array}{c}\text { Elev } \\
\text { ation }\end{array}$ & $\begin{array}{c}\text { Azi } \\
\text { mut } \\
\mathrm{h}\end{array}$ & $\begin{array}{c}\text { Elev } \\
\text { ation }\end{array}$ & $\begin{array}{c}\text { Azi } \\
\text { mut } \\
\mathrm{h}\end{array}$ & $\begin{array}{c}\text { Elev } \\
\text { ation }\end{array}$ & $\begin{array}{c}\text { Azi } \\
\text { mut } \\
\mathrm{h}\end{array}$ & $\begin{array}{c}\text { Elev } \\
\text { ation }\end{array}$ \\
\hline $1^{*}$ & 71.1 & 71.5 & 71.4 & 71.9 & 8.80 & 8.20 & 8.80 & 8.10 \\
\hline
\end{tabular}

\begin{tabular}{|c|c|c|c|c|c|c|c|c|}
\hline & & & 3 & 4 & & & & \\
\hline 2.2 & 70.1 & 71.5 & 71.0 & $\begin{array}{c}71.5 \\
3\end{array}$ & 8.70 & 8.08 & 8.65 & 8.00 \\
\hline 3.2 & 69.9 & 71.2 & $\begin{array}{c}70.7 \\
2\end{array}$ & $\begin{array}{c}72.1 \\
4\end{array}$ & 8.65 & 8.17 & 8.60 & 8.20 \\
\hline 4.8 & 69.5 & 71.0 & $\begin{array}{c}70.2 \\
4\end{array}$ & $\begin{array}{c}71.6 \\
2\end{array}$ & 8.70 & 8.28 & 8.60 & 8.30 \\
\hline 10.2 & 68.5 & 73.0 & $\begin{array}{c}68.5 \\
1\end{array}$ & $\begin{array}{c}73.8 \\
5\end{array}$ & 8.88 & 8.59 & 8.75 & 8.55 \\
\hline
\end{tabular}

*without dielectric superstrate

\section{RESULTS AND DISCUSSION}

The measured and simulated return-loss and radiation patterns of patch antenna with superstrates are shown inFig.6 to Fig.9. From Figs. 6 \& 7, it can be observed that the resonant frequency shifted to lower valve which is $2.40 \mathrm{GHz}$ to $2.08 \mathrm{GHz}$. It is also observed that the impedance bandwidth without dielectric superstrate is $0.04 \mathrm{GHz}$. The impedance bandwidth with dielectric superstrate decreases as there is an increase in the dielectric constants of the superstrates. The impedance bandwidth with superstrates for various dielectric constant $\epsilon_{r 2}=2.2,3.2,4.8$ and 10.2 is about $0.03 \mathrm{GHz}$. The other parameters such as half power beam-width and gain is measured without superstrate. The results show that 70.80 degree in azimuth plane and 71.10 degree in elevation plane. Antenna with superstrate which shows that the beam-width slightly decreased in azimuth plane and increased in elevation plane is shown in Table III and Table V. The simulated and measured gain calculated in antenna without superstrate is $8.77 \mathrm{~dB}$ in azimuth plane and $8.10 \mathrm{~dB}$ in elevation plane.

\section{CONCLUSION}

In the case of different dielectric constants of superstrates, it has been observed that HPBW decreases in azimuth plane whereas it increases in the elevation plane. The gain and BW is decreasing as increasing dielectric constant of superstrates. VSWR and return loss increases as increasing dielectric constant of the superstrates.

\section{ACKNOWLEDGMENT}

The author expresses his deep gratitude to the Department of ECE, MGIT, for their encouragement during this work.

\section{REFERENCES}

1. I J Bhal and P Bhartia, "Microstrip antennas", Artech house, 1980.

2. Balanis, C.A., Antenna Theory: Analysis and Design, John Wiley\& Sons.

3. Hussain, A. Hammus, "Radiation performance evaluation of microstrip antenna covered with a dielectric layer", Eng\& Tech Journal, vol.27, 2009.

4. P. Malathi AND Rajkumar" Design of multilayer rectangular microstrip antenna using artificial neural networks" International journal of recent trends in Engineering, vol.2, no.5, Nov. 2009.

5. P. Malathi and Rajkumar" Design of multilayer rectangular microstrip antenna using artificial neural networks" International journal of recent trends in Engineering, vol.2, no.5, Nov. 2009

6. Christopher J Meagher and Satish kumar Sharm "A wide band aperture- coupled microstrip patch antennas employing space \& dielectric cover for enhanced gain performance, IEEE Transaction on antenna and propagation, Vol.58, No.9, Sep. 2010 
7. R.K.Yadav,R.L.Yadava "Performance Analysis of superstrate loaded patch antenna and Abstain from environmental Effects"International Journal of Engineering science and Tech., vol.3, no.8, p.p.6582-6591, Aug. 2011

8. H.Attia, L.Yousefi and O.M.Ramahi” Analytical model for calculating the radiation fields of MSA with artificial maganetic superstrates: Theory and experiment. IEEE Tranc. Antennas and wave progation, vol.59,2011

9. M..Younssi,A.Jaoujal" Study of MSA with and without superstrate for Terahz frequency', ISSR Journal, 2013

10. Chirag Arora, Shyam S.Pattnaik and R.N. Baral, "Multiple Split Ring Resonator Inspired Dual Band Microstrip Patch Antenna Array" Microwave Review in June, 2019.

11. Harshit Srivastava and Usha Tiwari "Design, Simulation \& Analysis of Rectangular \& Circular Microstrip patch antenna for Wireless Applications, International Journal of Recent Technology and Engineering, ISSN. 2277-3878,Volume.8, Issue. 4, November 2019.

\section{AUTHOR'S PROFILE}

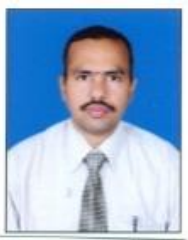

Dr. V. Saidulu, received B.Tech and M.Tech degree from Nagarjuna University, A.P and Banaras Hindu University, U.P.respectively. He received his $\mathrm{Ph} . \mathrm{D}$ degree from JNTUH, Hyderabad. Currently he is working as Associate Prof. in ECE Department, MGIT, Hyderabad. His research area is antennas and mobile communications. He has more than 25 papers published to his credit. 